Journal of

Business and Strategic

Management

(JBSM)

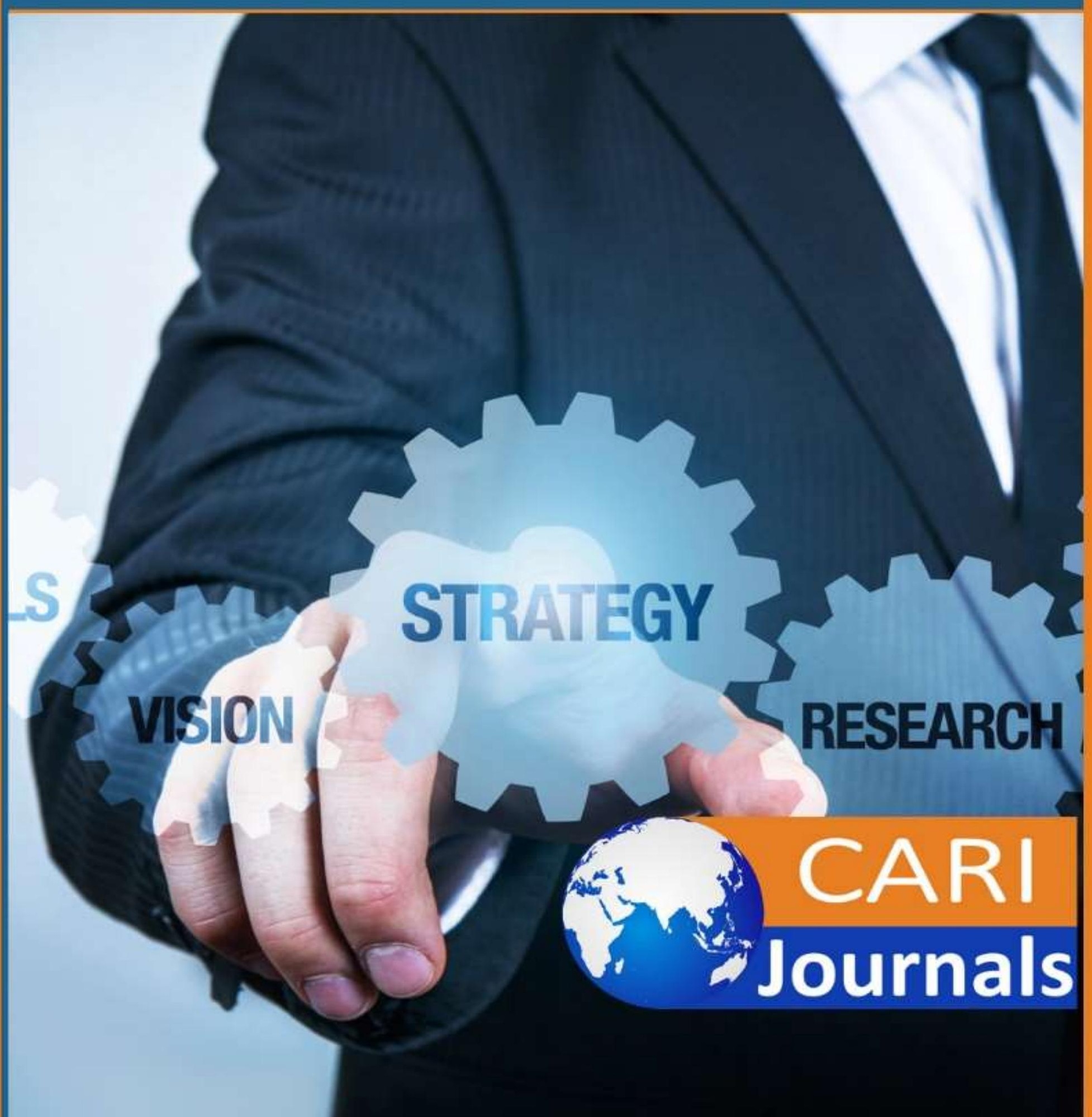




\title{
INFLUENCE OF FINANCIAL CAPABILITIES ON COMPETITIVENESS OF FOOD AND BEVERAGE MANUFACTURING FIRMS IN KENYA
}

\author{
Muiruri Edward Maina
}

\begin{abstract}
Post-graduate student: Department of Entrepreneurship and Procurement
\end{abstract}
Dr. Patrick Karanja Ngugi

Lecturer: Department of Entrepreneurship and Procurement

\author{
PhD JKUAT, Kenya \\ Dr. Allan Kihara
}

Lecturer: Department of Entrepreneurship and Procurement

PhD JKUAT, Kenya

Corresponding Authors Email: mmuiruri194@gmail.com

\begin{abstract}
Purpose: The firms have been facing steep competition from foreign companies due to increased globalization. The aim of the study was to find out the influence of financial capabilities on competitiveness of food and beverage processing companies in Kenya.

Methodology: The study was informed by resource based theory. Empirical studies were reviewed to provide the basis for research gaps to be filled by the current study. Descriptive research design was employed while the target population was the 187 food and beverage processing firms in Kenya. A census was used where all the 187 companies were contacted. Structured questionnaire was used to obtain the primary data which was analyzed through mixed method analysis. Descriptive statistics were used to analyze quantitative data while qualitative data was analyzed through content analysis. Inferential statistics were used to analyze the relationship between variables through the regression model. The findings were presented in form of tables, pie-charts and bar-graphs.

Results: The companies however mainly relied on bank deposits as the source of funding for their operations. Financial capabilities significantly and positively influence the competitiveness of the food and beverage processing firms. The bank deposits, cash holdings and stock holdings create the financial muscle of the firms by ensuring that they are able to obtain adequate and high quality production inputs thus contributing to the companies' success. The correlation analysis revealed that there was a positive and significant association between Financial capabilities and firm competitiveness $(r=0.698, p=0.000)$. Regression of coefficients results revealed that Financial capabilities and firm competitiveness are positively and significantly related $(\beta=0.638, p=0.000)$.
\end{abstract}


Journal of Business and Strategic Management

ISSN 2520-0402 (Online)

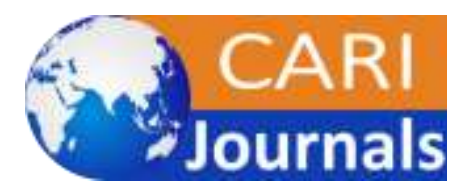

Vol.6, Issue No. 2, pp 25-41, 2021

www.carijournals.org

Unique contribution to theory, practice and policy: The firms ought to seek adequate financial capabilities as a way of effectively financing their operations to gain competitiveness. The companies should embrace accountability and proper investments that increase their bank deposits, cash holdings and stock holdings through which they can sustain their operations towards competitiveness. The companies should embrace accountability and proper investments that increase their bank deposits, cash holdings and stock holdings through which they can sustain their operations towards competitiveness.

Key words: financial capabilities, competitiveness, bank deposits, cash holdings, stock holdings

\section{INTRODUCTION}

\section{Background of the study}

Strategic management is the process and approach of specifying an organization's objectives, developing policies and plans to achieve and attain these objectives, and allocating resources so as to implement the policies and plans (Foss, Klein, Lien \& Zenger, 2020). Scholars in the area of strategic management have been interested in understanding sources of organizational renewal, growth, firm competitiveness and generation of entrepreneurial rents (Wang \& Yen, 2012).

Strategic drivers have been portrayed as the pillar of organizational competitiveness and performance through which an organization plans and strives towards achieving its goals regardless of the dynamism in the modern market (Mapetere, Mavhiki, Nyamwanza, Sikomwe \& Mhonde, 2012). In Egypt, Oltra and Flor (2010) analysed the moderating effect of business strategy on firm performance and found that business strategy such as availing financial and human resources and adoption of information technology had a direct influence on firm performance. According to Oltra and Flor (2010), business strategy can best be viewed as a strategic driver of business growth and performance and can be viewed in terms of the firm's ability to analyse the ability and strengths of the competitors and make decisions that exceed the thinking of the competitors.

To achieve competitiveness, there are factors that firm uphold which include mergers, acquisition, diversification, market efficiency, cost differentiation and strategic alliances (Baark, Lau, Lo \& Sharif, 2018). These aspects place the organization at the state of penetrating new markets and producing quality products at lower costs thus getting higher rank as far as competitiveness is concerned. Use of technology and innovation as well as enhancing human resources and organization structure are other approaches that modern organizations pursue so as to gain competitiveness (Ortiz \& Pacheco, 2013).

Firms under the same business strive to establish superiority to their customers. Each firm implements new ideas to improve its productivity and services to the customers over the other firm. According to Smith, Ferrier and Ndofor (2014), competition is the activity in which two or more parties, mostly organizations, individuals, animals, entities or economic groups strive to win something over the others. Therefore, firm competition, as the term competition is described by Smith et al. (2014), means the condition of the firms under one business striving to increase its output over the other firms. Mutunga, Minja and Gachanja (2014) described firm competition as a 
Journal of Business and Strategic Management

ISSN 2520-0402 (Online)

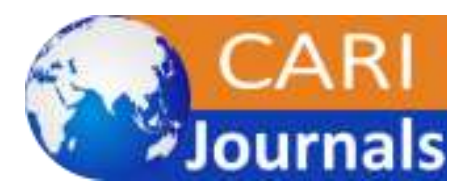

Vol.6, Issue No. 2, pp 25-41, 2021

www.carijournals.org

process in which two or more firms in the same insomnia business undergo to improve customer needs and provide better services for big output. Moghli, Abdallah and Muala (2012) refer firm competition to an embedment in relationship among firms with network of suppliers, buyers as well as competitors that help them to gain competitiveness in the sales of product and services.

Developing a sustainable competitiveness in the competitive market setting is the main challenge that most firms face. Pernierl (2015) defines competitiveness as the leverage that a business has over its competitors. Porter contends that an association can accomplish aggressiveness over its rivals in two different ways: cost bit of leeway and separation advantage. Cost favorable position is the point at which a business gives indistinguishable items and administrations from its rivals, yet at a lesser expense (Dhungana, 2013). Separation favorable position is the point at which a business gives better items and administrations as its rivals. In Porter's view, vital administration ought to be worried about structure and supporting aggressiveness.

The food industry is vast and diversified, categorized by different segments such as fresh food industry, organic food industry, processed food industry and livestock food industry. Kenya's economy has remained to a great extent agribusiness based and industrialization stays a key factor in Kenya's improvement plans (ROK, 2007). Nourishment creation has consistently been a precondition for the advancement of human progress (Kenya Institute for Public Policy Research and Analysis, 2013). Kenyan manufacturing firms are facing greater performance challenges and competitive pressures from both local and multinational organizations. The Kenyan food and beverage industry is experiencing an increase in competition with new entrants in the market, changes in environmental conditions thus affecting inputs as well as increased tastes and preferences taking the lead.

According to Munguti, (2014) the field of food manufacturing, there involves beverages, dairy products, foods, vegetables, fruits, meat, nuts, mushroom among others. The sub-sector makes over $30 \%$ of Kenya' manufacturing sector. It is one of the major channels of value addition of the agricultural products thus it is interdependent with the agricultural sector. This is to mean that for the food processing sector to grow, there ought to be high rate of agricultural productions while at the same time for the agricultural sector to make more returns the food sector ought to penetrate more markets and offer high value products. According to the reports by KNBS (2016), the entire Kenya's manufacturing sector contributes to approximately $10 \%$ of the country's Gross Domestic Product (GDP) while on the same note, food manufacturing contributes to $33.4 \%$ of the total annual output by the manufacturing sector. This is to mean that the food manufacturing sub-sector in Kenya is a key economic driver that cannot be overlooked hence the focus of the study.

\section{Statement of the Problem}

The Kenyan food and beverage manufacturing sector has recorded dismal performance compared to other sectors. Statistics from the Kenya National Bureau of Statistics showed that the sector performed dismally compared to other sectors with a growth rate of 3.5\% between the year 2014 and 2017 as compared to Agriculture which posted 4.4 percent, energy 6.5 percent, transport and storage 7.2 percent and building and construction at 9.2 percent (KPMG, 2017; ROK, 2018; KAM, 2018). 
Journal of Business and Strategic Management

ISSN 2520-0402 (Online)

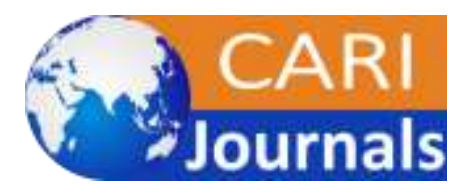

Vol.6, Issue No. 2, pp 25-41, 2021

www.carijournals.org

Previous evidence shows that strategic drivers are key aspects that immensely contribute to firm competitiveness (Gates, 2010; Fayol \& Storrs, 2013; Muia, 2011). The main argument goes that strategic drivers enable a firm to create innovations, take advantage of new opportunities as well as improve its business model for better performance (Ribau, Moreira \& Raposo, 2016).

Empirical studies have shown mixed results on the relationship between strategic drivers and competitiveness of business organizations. In their study on effects of strategic management drivers on the performance of hotel industry in Kenyan Coast, Mutindi, Namusonge and Obwogi (2013) found that adopting key strategic drivers such as Information Communication Technology and customer relationship management had a significant influence on firm competitiveness. Chijioke, $\mathrm{Vu}$ and Olatunji (2018) influence of strategic drivers on performance of government organizations in Malawi found that as a result of focusing on human capital and customers as strategic drivers, firm strategies were achieved thus enhancing competitiveness. On the other hand, Porck, Knippenberg and Groenen (2020) in their study on strategic management drivers and firm performance; a case of financial institutions in Pakistan established that strategic drivers only contributed to minimal success of a strategy and had insignificant direct relationship with firm competitiveness. Decramer (2015) while looking for the value of strategic drivers in firm performance and competitiveness found that focusing on strategic drivers shifted the competencies and capabilities of the firms to the drivers more than to the strategies themselves thus affecting competitiveness and performance negatively. Tafirei (2014) on a comparative study of strategic drivers of SMEs and large-sized business organizations found no direct relationship between strategic drivers and competitiveness of firms in Sweden.

The above studies present a contradictory argument on the relationship between financial capabilities and organizational competitiveness. This therefore puts across the need for a study to fill the existing gaps and clear the doubt on the influence of financial capabilities on firm competitiveness. It is on this background that the study sought to answer the question; can the financial capabilities be the solution to the competitiveness of food and beverage manufacturing firms in Kenya?

\section{General Objective}

The aim of the study was to find out the influence of financial capabilities on competitiveness of food and beverage processing companies in Kenya.

\section{LITERATURE REVIEW}

\section{Resource Based Theory}

The resource based theory was first introduced by Penrose (1959) but has extensively been elucidated by Barney and Clark (2007) as an attempt to explain how organizations can strategically place themselves in the market through utilization of available resources. The theory emphasizes that the firm's resources as the fundamental determinants of competitiveness and performance. Resource-based view has turned out to be one of the most compelling and referred to speculations throughout the entire existence of the board conjecturing. It tries to clarify the interior wellsprings of a company's continued aggressiveness (Kraaijenbrink, Spender, and Groen, 2010). It was Penrose who set up the establishments of the resourced-based view as a hypothesis (Dunkelberg, 
Journal of Business and Strategic Management

ISSN 2520-0402 (Online)

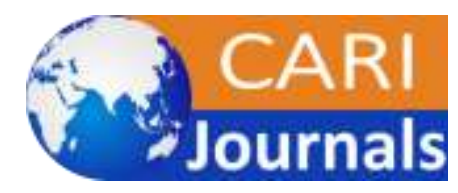

Vol.6, Issue No. 2, pp 25-41, 2021

www.carijournals.org

Moore, Scott and Stull, 2013). Penrose first gives an intelligent clarification to the development pace of the firm by explaining the causal connections among firm assets, creation ability and execution.

Barney's (1991) concern is mostly on productive and imaginative utilization of assets. She asserted that groups of gainful assets constrained by firms could fluctuate altogether by firm, that organizations in this sense are essentially heterogeneous regardless of whether they are in a similar industry (Barney and Clark, 2007). Wernerfelt (1984) took on an asset point of view to break down forerunners of items and at last hierarchical execution and accepted that assets and items are two of a kind and firms expand dependent on accessible assets and keep on amassing through procurement practices.

The learning based writing of the firm encourages and builds up the asset based hypothesis in that it believes information to be the most unpredictable of an association's assets (Alavi and Leidner, 2001). As indicated by asset based hypothesis, the scholarly capital (IC) is a primary source to improve organization development. In this manner, scholarly capital has been considered by numerous individuals past analysts who research the impact of scholarly capital on business execution. Be that as it may, most past specialists concentrated on the effect of individual scholarly capital on execution while disregarding the impacts of explicit components of scholarly capital.

The present overwhelming perspective on business procedure - asset based hypothesis or asset based view (RBV) of firms - depends on the idea of financial lease and the perspective on the organization as a gathering of abilities. This perspective on system has an intelligence and integrative job that spots it well in front of different instruments of vital basic leadership. Ganotakis and Love (2010) utilized the Resource Based Theory (RBT) to clarify the significance of human funding to business enterprise. As indicated by RBT, human capital is viewed as a wellspring of aggressiveness for pioneering firms.

Responsibility for explicit resources empowers an organization to create aggressiveness. This prompts quirky blessings of exclusive assets (Peppard and Rylander, 2001). As per RBT, manageable aggressiveness results from assets that are supreme, not substitutable, unsaid in nature, and synergistic (Barney, 1991). Along these lines, administrators should have the option to distinguish the secret weapons and drivers of execution and incentive in their associations.

The RBT additionally expresses that an organization's intensity is gotten from the organization's capacity to collect and adventure a suitable blend of assets. Such assets can be unmistakable or impalpable, and speak to the contributions to an association's generation procedure, for example, capital, gear, the abilities of individual representatives, licenses, financing, and skilled chiefs. As an organization's adequacy and capacities increment, the arrangement of accessible assets will in general become bigger. Through continued use, these capabilities, defined as the capacity for a set of resources to interactively perform a stretch task or an activity, become stronger and more difficult for competitors to understand and imitate. This theory therefore is adopted in the study to inform the study on how financial resource as one of the resources in an organization contributes to competitiveness. 
Journal of Business and Strategic Management

ISSN 2520-0402 (Online)

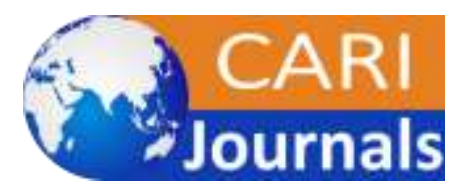

Vol.6, Issue No. 2, pp 25-41, 2021

$\underline{\text { www.carijournals.org }}$

\section{Empirical review}

Fonseka, Tian and Li (2014) conducted a study to investigate the impact of different sources of external financing and internal financial capabilities on competitiveness and sustainability. Based on balanced panel of 4,530 firm-year observations, hierarchical regressions were used to examine the research model. Results support the idea that the strict Chinese regulatory regime allows some firms to access capital and debt markets for financing more than others. It was found that firms' internal financing abilities do not offer a significant advantage compared to external financing abilities; firms' abilities to raise capital from existing shareholders, the public and easy access to bank financing are related positively for an advantage on firm's competitiveness within an industry.

López Salazar, Contreras Soto and Espinosa Mosqueda (2012) examined the financial decisions made by companies, the strategies that organizations follow, the alignment between these two variables, and the relationship of financial decisions to the level of competitiveness. Two hundred two businesses' testimonies in the region of Celaya were analyzed. The results show that most micro and small enterprises make funding decisions in a certain way, apply an intensive strategy, also that their market longevity is low and their level of sales is regular, implying that Mexican companies lack competitiveness, which hampers their development and expansion. The emphasis that companies place on certain financial decisions is not always appropriate for the type of business strategy being implemented. Likewise, companies that efficiently manage their shortterm assets and liabilities are more competitive, as evaluated by their longevity on the market.

In their findings, Klingebiel and Rammer (2014) stated that allocation of resources to the organizational departments, led to enhanced innovativeness among the employees and this enhanced the performance of the departments and the organizations in particular. Klingebiel and Rammer (2014) further found that many performing organizations in UK laid more emphasizes on innovativeness as a competitive strategy and it's on this basis that measures were taken by the organizations to enhance innovativeness among them being resource allocation.

Faderai (2016) did a study on the impacts of adequate resource allocation on performance of government owned firms in Ghana. The study aimed at establishing the ability of effective resource allocation to enhance performance of government institutions (Faderai, 2016). The study employed descriptive survey research design and had a sample of 109 respondents. Faderai (2016) found that most of the government owned firms in Nigeria were underfunded and this affected their performance negatively. Faderai (2016) further established that most of the projects by government firms were given little attention and monitoring thus giving some individuals a chance to misappropriate the resources allocated to the projects thus leading to their collapse. Faderai (2016) concluded that resource allocation was an essential aspect of ensuring success of organizational projects and performance of the organization in the long run.

Locally, Kanyari and Namusonge (2017) carried out a study on the influence of resource orientation on the performance of youth owned firms in Kenya. The study aimed at establishing the extent to which availability and accessibility of resources such as financing and other firm inputs enhance performance of youth owned firms in Kenya. The study adopted a correlation research design and had a sample of 384 respondents drawn from youth owned firms in Nairobi 
Journal of Business and Strategic Management

ISSN 2520-0402 (Online)

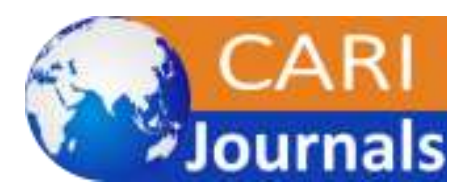

Vol.6, Issue No. 2, pp 25-41, 2021

www.carijournals.org

and Kiambu Counties. The study established that a positive and significant relationship existed between resource orientation and performance of youth owned firms. According to Kanyari et al. (2015), sound resource capacity enables the firms tap into the evolving opportunities riding on the fast mover advantage. It also enables them to deploy robust IT platforms enhancing their operational efficiency while expanding their market territories through green field and acquisitions strategies.

\section{RESEARCH METHODOLOGY}

The study employed a positivist research philosophy since it deals with quantitative data which is precise and therefore can be easily compared thus generating reliable evidence from the responses collected through use of questionnaires. According to Ashley and Orenstein (2005), the positivism school of thought is grounded on the philosophy that only one reality exist though can only be known imperfectly due to human limitations and researchers can only discover this reality within the realm of probability.

This study employed a descriptive research design. A descriptive research design is used when the problem has been well designed and where the researcher can engage in a field survey by going to the population of interest in order for the respondents to explain certain features about the problem under study (Creswell, 2013). The design was therefore considered appropriate since it is more precise and accurate as it involves description of events in a carefully planned way (Babbie, 2012). Population is a group of individuals, objects or items from which samples are taken for measurement. The target population for this study was the food and beverage processing firms in Kenya. These are manufacturing firms that deal with production, packaging and distribution of food and related products and beverages (KAM, 2016).

As of December 2018, there were 187 food and beverage processing firms in Kenya registered under KAM (KAM, 2018). The unit of analysis therefore was 187 food and beverage processing firms. the study focused on one staff member at the management level in the one-hundred and eighty seven (187) food and beverage processing firms in Kenya, this being the unit of observation. A Census survey was conducted on all the 187 Food and Beverage processing firms registered with the Kenya Association of Manufacturers being the unit of analysis. The unit of observation comprised of one senior manager in the relevant field for the 187 Food and Beverage processing firms. This gave a total sample size of 187 respondents.

Primary data was used for this study and was collected using structured questionnaires. The questionnaires included both closed and open ended questions. A register of questionnaires was maintained showing the ones which are issued and the ones received. The questionnaire was administered using a drop and pick later method to the respondents. This study as well carried out a pilot test. This was done by use of $10 \%$ of the sample size which totaled to 19 firms. These were not included in the final study.

Content analysis was used in processing of this data and results presented in prose form. The quantitative data in this research was analyzed by descriptive statistics using statistical package for social sciences (SPSS). Descriptive statistics captured included mean, frequency, standard deviation and percentages to profile sample characteristics and major patterns emerging from the 
Journal of Business and Strategic Management

ISSN 2520-0402 (Online)

Vol.6, Issue No. 2, pp 25-41, 2021

$\underline{\text { www.carijournals.org }}$

data. Inferential statistics were used to analyze the relationship between variables through the regression model. The findings were presented in form of tables, pie-charts and bar-graphs.

\section{FINDINGS AND DISCUSSIONS}

\section{Response Rate}

A total of 187 questionnaires were issued to the respondents and a total of 132 questionnaires were recollected for analysis. This makes a response rate of $71 \%$ which was considered adequate for analysis.

\section{Descriptive statistics}

The study sought to find out the resultant impact of Financial capabilities on the firm competitiveness. The specific elements that the study addressed were: available bank deposits, monitoring of the level of the available bank deposits, bank deposits channeling to short-term investments, firm cash holdings to support its operations, cash and reserve cash for day-to-day use and emergency use, diverse investments to ensure long term cash inflows, stock holdings and value of assets. The rates of the measures were assessed on the practice of the measures.

\section{Financial capabilities adequacy}

The research assessed the rating of the adequacy in the Financial capabilities in the firms which include bank deposits, cash holdings and stock holdings. Table 1 gives the illustration of the findings.

Table 1 Adequacy of Financial capabilities

\begin{tabular}{lccccccc}
\hline Measure & $\begin{array}{c}\text { Very } \\
\text { Inadequate }\end{array}$ & $\begin{array}{c}\text { Inadequ } \\
\text { ate }\end{array}$ & $\begin{array}{c}\text { Not } \\
\text { sure }\end{array}$ & $\begin{array}{c}\text { Adequat } \\
\text { e }\end{array}$ & $\begin{array}{c}\text { Very } \\
\text { adequate }\end{array}$ & $\begin{array}{c}\text { Mean } \\
\text { Dev. }\end{array}$ \\
\hline $\begin{array}{l}\text { Bank } \\
\begin{array}{l}\text { Deposits } \\
\text { Cash }\end{array}\end{array}$ & $5.30 \%$ & $8.30 \%$ & $1.50 \%$ & $65.90 \%$ & $18.90 \%$ & 3.8 & 1 \\
$\begin{array}{l}\text { holdings } \\
\begin{array}{l}\text { Stock } \\
\text { holdings }\end{array}\end{array}$ & $15.20 \%$ & $0.00 \%$ & $11.40 \%$ & $50.00 \%$ & $23.50 \%$ & 3.7 & 1.3 \\
\hline
\end{tabular}

In an organization, the adequacy of the bank deposits should be a main concern. Illustration in Table 1 revealed that the majority of the respondents $(75 \%)$ indicated that the bank deposits are adequate, $1 \%$ indicated that they are not sure of the adequacy rating whereas $14 \%$ indicated that the bank deposits are inadequate in the firms. According to Hayness, Walker and Hong, (2013), bank deposits are some of the Financial capabilities that a company relies on in order to enhance its operations. These are the deposits made by the company to the bank as savings from which they draw their financing to the operations.

The adequacy of cash holding that are useful in the recurrent expenditures in the firm operations were assessed and the findings revealed that majority (74\%) indicated that the firms have adequate 
Journal of Business and Strategic Management

ISSN 2520-0402 (Online)

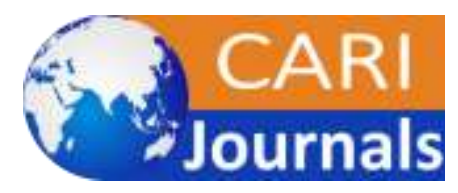

Vol.6, Issue No. 2, pp 25-41, 2021

www.carijournals.org

cash holdings, $11 \%$ indicated their uncertainty of cash holdings where as $15 \%$ of the respondents indicated that the cash holdings are very inadequate.

The stock holdings are necessary in all firm operations. Among holdings the respondents, $83 \%$ of the respondents indicated there are adequate stock holdings in the firm, $4 \%$ indicated they are not sure of the firm stock holdings while $13 \%$ noted that the firm have inadequate stock holdings. Ahokangas and Myllykoski (2014) notes that resource mobilization is considered as one of the competitive strategies that seek to enhance the performance and competitiveness of the firm. Reeb (2016) also notes that allocating resources to the organizational projects remains a key move towards sustaining the organizational performance.

\section{Bank deposits adequacy for competitiveness}

The research assessed the adequacy rating of the deposits in effort to foster competitiveness in organizations. The results in Table 2 revealed that the majority $(85 \%)$ were in agreement that the available bank deposits by the respective organizations are adequate to steer its competitiveness, $6 \%$ had a neutral opinion on the statement whereas $9 \%$ totally disagreed with the statement. The mean and standard deviation of the responses was 4.2 and 1.04 respectively.

Similar findings were revealed by Klingebiel and Rammer (2014) that allocation of resources to the organizational departments, led to enhanced innovativeness among the employees and this enhanced the performance of the departments and the organizations. Karanja, Otieno and Kagone (2015) also revealed a positive and significant relationship existed between resource orientation and performance of youth owned firms.

\section{Monitoring of available bank deposits}

The research assessed the monitoring of the bank deposits practice to enhance sustainability of the operations. Among the respondents, majority (86\%) were in agreement that the organizations monitors the level of the available bank deposits to ensure they are capable of supporting its operations, $5 \%$ were undecided whereas $9 \%$ disagreed with the opinion. The responses on this statement had a mean and standard deviation of 4.2 and 0.96 respectively.

\section{Bank deposits and investments}

The research assessed the practice of short term investments using the available bank deposits. The illustrations in Table 2 revealed that the majority (86\%) of the respondents were in agreement that some of the available bank deposits are directed to short-term investments to ensure adequate cash inflows in the organizations, $6 \%$ had a neutral opinion whereas $8 \%$ disagreed with the statement. The mean of the statement opinion was 4.5 and had a low standard deviation of 1.05.

Vargas (2015) noted similarly that engagement in investment is the total worth of a company which reciprocates the ability of the firm to make investments thus standing a better chance to manage risks and remain competitive.

\section{Operation cash holding}

The research assessed the adequacy of the cash holding for operations of the organization. Results in Table 2 revealed that the majority $(82 \%)$ of the respondents were in agreement that the respective firms have adequate cash holdings to support their operations, $6 \%$ had a neutral opinion 
Journal of Business and Strategic Management

ISSN 2520-0402 (Online)

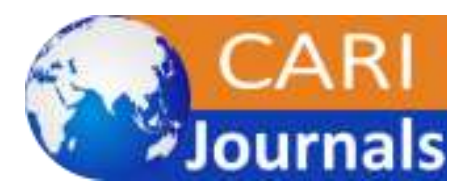

Vol.6, Issue No. 2, pp 25-41, 2021

www.carijournals.org

over the issue while $12 \%$ totally disagreed on the adequacy of cash holding in the firms. The mean of the statement opinion was 4.2 while the standard deviation was low at 1.14. Similar findings were found by Faderai (2016) who established that most of the projects by government firms were given little attention and monitoring thus giving some individuals a chance to misappropriate the resources allocated to the projects thus leading to their collapse. Therefore, monitoring of funds is crucial.

\section{Cash reservation for daily expenses and emergency}

The research assessed the availability of reservation of cash to address the daily expenses in the organization and the emergency operations. The results in Table 2 revealed that the majority (85\%) agreed that the companies' cash holding has been split into vault cash and reserve cash for day-today use and emergency use respectively, $7 \%$ had a neutral opinion whereas $8 \%$ disagreed with the statement. The mean of the statement opinion was 4.2 and had a low standard deviation of 0.99 .

Related findings were found by Karanja et al. (2015), who indicated that sound resource capacity and holding enables the firms tap into the evolving opportunities riding on the fast mover advantage enhancing their operational efficiency while expanding their market territories through green field and acquisitions strategies.

\section{Diversity of investments}

The research assessed the expansion of cash inflows through diversification of investments by the firm. The illustrations in Table 2 revealed that the majority of the respondents $(84 \%)$ were in agreement that the firms have diverse investments to ensure long term cash inflows for continued competitiveness, $8 \%$ had a neutral opinion while $8 \%$ disagreed with the opinion of diversity of investments in the firms. The mean of the opinion was high at 4.1 while the standard deviation was at 0.91 .

Vargas (2015) similarly indicated that firm that make investments stand a better chance to manage risks and remain competitive. Dávila, North, \& Varvakis (2016) noted that for an organization to gain competitiveness, it must either invest on systems and processes to enhance quality while matching the quality with that of the competitors.

\section{Available stocks adequacy}

The research assessed the adequacy of the stock available to support the near and distance future of the firms. The majority $(81 \%)$ as per Table 2 were in agreement that the stocks available in the firms are adequate to support its operations for the foreseeable future, $7 \%$ were undecided on the statement opinion whereas $12 \%$ disagreed with the statement that the stock adequacy in the firm is guaranteed. The mean of the opinion was high at 4.2 while the standard deviation was at 1.15.

\section{Policy measures application for stock holdings}

The research assessed whether the respective firms have installed the stock holdings practices for financial balancing in the firms. As per Table 2, majority (84\%) indicated that the firms have put appropriate measures to maintain its stock holdings for better financing of its operations, $9 \%$ were uncertain of their opinion whereas $7 \%$ disagreed with the opinion statement. The mean of the opinion was high at 4.2 while the standard deviation was at 0.95 . 
Journal of Business and Strategic Management

ISSN 2520-0402 (Online)

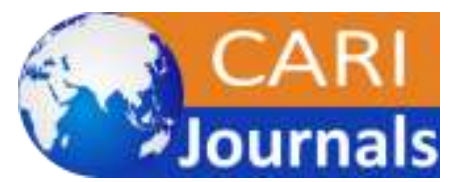

Vol.6, Issue No. 2, pp 25-41, 2021

$\underline{\text { www.carijournals.org }}$

Oyarzo (2011) similarly indicated that adoption of measures on stock and operations encompasses the ability of the organization to ensure appropriate measures and systems are aligned so as to enhance successful adoption of stock regulation in order to enhance their operations.

\section{Value of assets increase}

The research assessed the value of assets impact on the firm competitiveness in a situation of value appreciation. The illustrations in Table 2 revealed that the majority of the respondents (85\%) were in agreement that the increase in value of assets has significantly improved competitiveness of the respective firms, $7 \%$ had a neutral opinion while $8 \%$ disagreed on the value of assets impact on firm competitiveness. The mean of the opinion was 4.1 while the standard deviation was at 0.89 .

Wagner (2012) noted that firm value of assets enhances the company's ability to meet its shortterm obligations using its most liquid assets. It is usually measured by the current assets to current liabilities. Liquid assets reveal the ability of an organization to convert its asset to cash quickly and reflect its ability to manage working capital when kept at normal levels.

Table 2 Financial capabilities

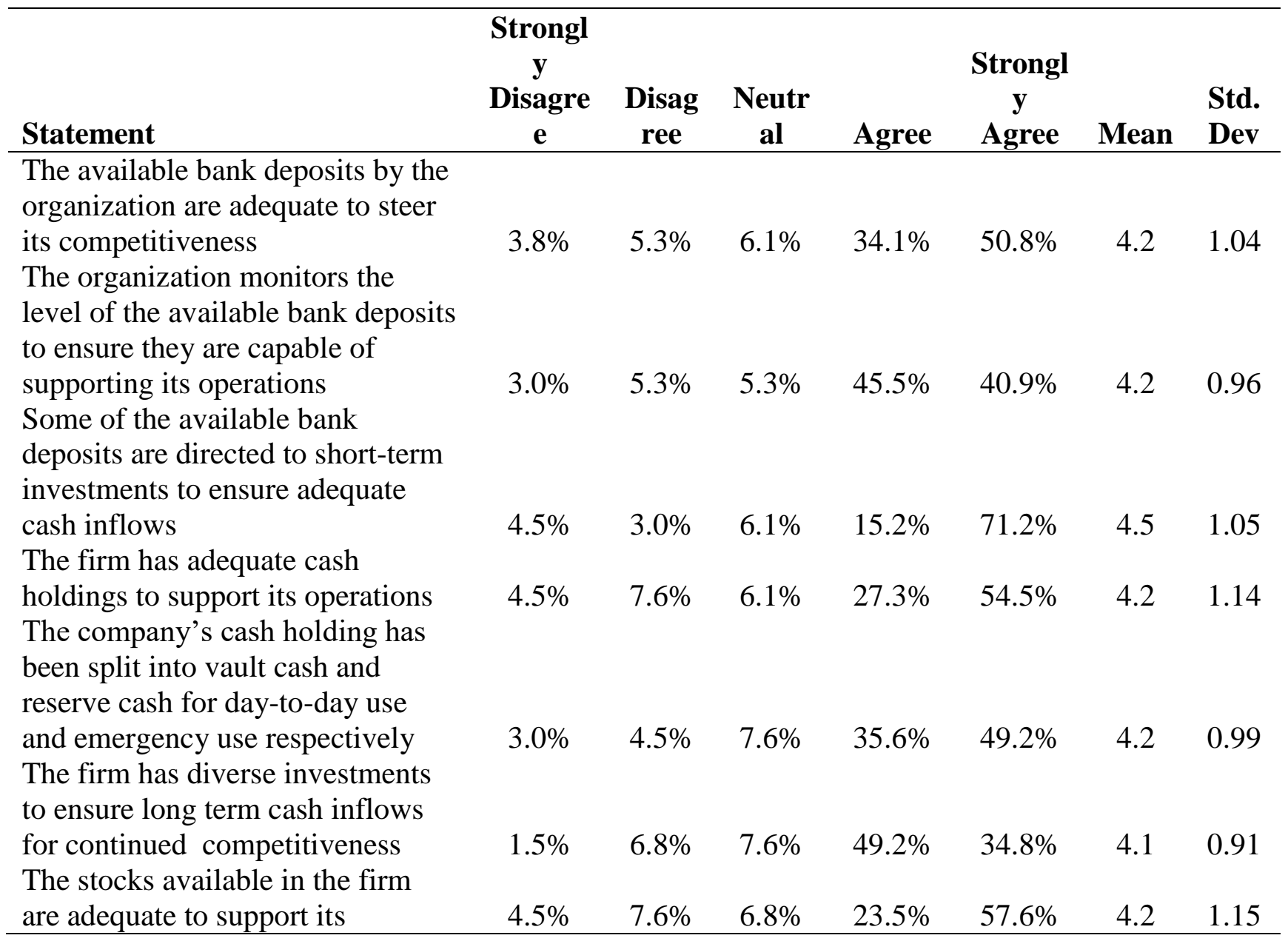


Journal of Business and Strategic Management

ISSN 2520-0402 (Online)

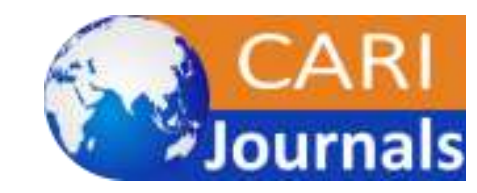

Vol.6, Issue No. 2, pp 25-41, 2021

www.carijournals.org

operations for the foreseeable

future

The firm has put appropriate

measures to maintain its stock

holdings for better financing of its

operations

$\begin{array}{lllllll}2.3 \% & 4.5 \% & 9.1 \% & 36.4 \% & 47.7 \% & 4.2 & 0.95\end{array}$

Increase in value of assets has

significantly improved

competitiveness of the firm

\begin{tabular}{lllllll}
$1.5 \%$ & $6.1 \%$ & $6.8 \%$ & $50.8 \%$ & $34.8 \%$ & 4.1 & 0.89 \\
\hline
\end{tabular}

\section{Correlation between Financial capabilities and firm competitiveness}

The study focused to obtain the relationship that exists between Financial capabilities and firm competitiveness.

Table 3 Correlation test of Financial capabilities

\begin{tabular}{llcc}
\hline & & Financial capabilities & Firm competitiveness \\
\hline Financial capabilities & \multicolumn{1}{c}{ Pearson Correlation } & 1 & $.698^{* *}$ \\
& \multicolumn{1}{c}{ Sig. (2-tailed) } & & 0.000 \\
Firm competitiveness & Pearson Correlation & $.698^{* *}$ & 1 \\
& Sig. (2-tailed) & 0.000 & \\
\hline
\end{tabular}

** Correlation is significant at the 0.01 level (2-tailed).

The results in Table 3 revealed that there was a positive and significant association between Financial capabilities and firm competitiveness $(r=0.698, p=0.000)$. This implies that Financial capabilities factors have contributed to the resulted to the firm competitiveness. This correlation coefficient value was between 0.6 and 0.7 indicating a strong positive correlation as a factor of firm competitiveness. A 2-tailed test at $95 \%$ level of confidence had a probability value of less than 0.05 which implied that there was a significant correlation between Financial capabilities and firm competitiveness in food and beverage processing companies.

\section{Regression analysis of financial capabilities on firm competitiveness}

Regression analysis was done to determine the influence of financial capabilities on firm competitiveness. Results were presented in Table 4.

Table 4 Model fitness

\begin{tabular}{lccc}
\hline R & R Square & Adjusted R Square & Std. Error of the Estimate \\
\hline $.698 \mathrm{a}$ & 0.488 & 0.484 & 0.3918 \\
\hline
\end{tabular}

The results in Table 4 presented the fitness of model of regression model used in explaining the study phenomena. Financial capabilities factor was found to be satisfactory in contribution as a 
Journal of Business and Strategic Management

ISSN 2520-0402 (Online)

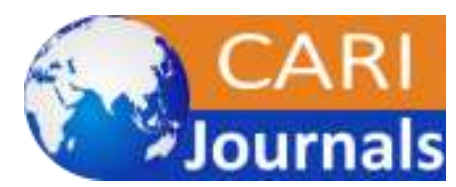

Vol.6, Issue No. 2, pp 25-41, 2021

www.carijournals.org

factor to firm competitiveness. This was supported by coefficient of determination i.e. the R square of $48.8 \%$. This shows that financial capabilities explain $48.8 \%$ of firm competitiveness. The results meant that the model applied to link the relationship. This also implies that $51.2 \%$ of the variation in the dependent variable is attributed to other variables not captured in the model.

Table 5 ANOVA for Financial capabilities

\begin{tabular}{lccccc}
\hline & Sum of Squares & df & Mean Square & F & Sig. \\
\hline Regression & 18.988 & 1 & 18.988 & 123.681 & $.000 \mathrm{~b}$ \\
Residual & 19.958 & 130 & 0.154 & & \\
Total & 38.946 & 131 & & & \\
\hline
\end{tabular}

Table 5 provided the results on the analysis of the variance (ANOVA). The results indicated that the model was statistically significant. This was supported by an F statistic of 123.681 and the reported $\mathrm{p}$ value $(0.000)$ which was less than the conventional probability of 0.05 significance level. The results implied that financial capabilities factor is a good predictor of firm competitiveness. Faderai (2016) did a study on the impacts of adequate resource allocation on performance of government owned firms and concluded that resource allocation was an essential aspect of ensuring success of organizational projects. Similarly, Karanja, Otieno and Kagone (2015) carried out a study on the influence of resource orientation on the performance of youth owned firms in Kenya and found a positive and significant relationship existed between resource orientation and performance of youth owned firms.

Table 6 Regression of coefficients for Financial capabilities

\begin{tabular}{|c|c|c|c|c|c|}
\hline & $\begin{array}{l}\text { Unst } \\
\text { B }\end{array}$ & $\begin{array}{l}\text { ficients } \\
\text { Std. } \\
\text { Error }\end{array}$ & $\begin{array}{c}\text { Standardized } \\
\text { Coefficients } \\
\text { Beta }\end{array}$ & $\mathbf{t}$ & Sig. \\
\hline (Constant) & 1.38 & 0.244 & & 5.653 & 0.000 \\
\hline $\begin{array}{l}\text { Financial } \\
\text { capabilities }\end{array}$ & 0.638 & 0.057 & 0.698 & 11.121 & 0.000 \\
\hline
\end{tabular}

Regression of coefficients results in Table 6 revealed that Financial capabilities and firm competitiveness are positively and significantly related $(\beta=0.638, \mathrm{p}=0.000)$. This implies that a unit increase in Financial capabilities would lead to increase in firm competitiveness by 0. 638.

\section{SUMMARY, CONCLUSION AND RECOMMENDATIONS}

\section{Summary}

The objective of the study aimed at determining the influence of Financial capabilities on competitiveness of Food and Beverage Processing Companies in Kenya. The correlation analysis revealed that there was a positive and significant association between Financial capabilities and 
Journal of Business and Strategic Management

ISSN 2520-0402 (Online)

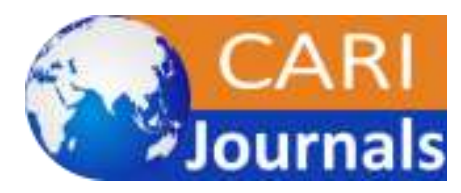

Vol.6, Issue No. 2, pp 25-41, 2021

www.carijournals.org

firm competitiveness $(r=0.698, p=0.000)$. This implies that Financial capabilities factors have contributed to the resulted to the firm competitiveness. This correlation coefficient value was between 0.6 and 0.7 indicating a strong positive correlation as a factor of firm competitiveness. A 2-tailed test at $95 \%$ level of confidence had a probability value of less than 0.05 which implied that there was a significant correlation between Financial capabilities and firm competitiveness in food and beverage processing companies. Regression of coefficients results revealed that Financial capabilities and firm competitiveness are positively and significantly related $(\beta=0.638, \mathrm{p}=0.000)$. This implies that a unit increase in Financial capabilities would lead to increase in firm competitiveness by 0.638 .

Among the key aspects of Financial capabilities include bank deposits, cash holdings and stock holdings in the firm. The findings indicated that the available bank deposits by the respective organizations are adequate to steer its competitiveness and boosting capability of supporting its operations. The bank deposits can be directed to short-term investments to ensure adequate cash inflows in the organizations. Diverse investments also ensure long term cash inflows. Majority of the companies' cash holding is split into vault cash and reserve cash for day-to-day use and emergency use according to the firm experiences. The stocks available in the firms are useful to support its operations for the foreseeable future. The study revealed that firms put appropriate measures to maintain their stock holdings and increase their value of assets for better financing of its operations.

\section{Conclusion}

Financial capabilities significantly and positively influence the competitiveness of the food and beverage processing firms. The bank deposits, cash holdings and stock holdings create the financial muscle of the firms by ensuring that they are able to obtain adequate and high quality production inputs thus contributing to the companies' success. It is therefore concluded that most of the food and beverage processing firms in Kenya have put Financial capabilities at the helm of their strategies and this could be the factor behind their current status of competitiveness.

\section{Recommendations}

The study recommended that the management of the food and beverage processing firms ought to embrace strategic drivers as a way of enhancing their competitiveness. The firms ought to seek adequate Financial capabilities as a way of effectively financing their operations to gain competitiveness. The companies should embrace accountability and proper investments that increase their bank deposits, cash holdings and stock holdings through which they can sustain their operations towards competitiveness.

\section{REFERENCES}

Alavi, M., \& Leidner, D. E. (2001). Knowledge management and knowledge management systems: Conceptual foundations and research issues. MIS quarterly, 107-136.

Ashley, D., \& Orenstein, D. M. (2005). Sociological theory: Classical statements. Pearson College Division. 
Journal of Business and Strategic Management

ISSN 2520-0402 (Online)

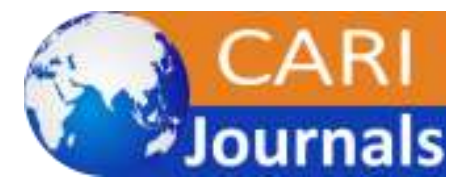

Vol.6, Issue No. 2, pp 25-41, 2021

www.carijournals.org

Baark, E., Lau, A. K. W., Lo, W., \& Sharif, N. (2018). Innovation sources, capabilities and competitiveness: Evidence from Hong Kong Firms. Paper presented at the Dynamics of Institutions $\&$ Markets in Europe (DIME) Final Conference, Maastrich.

Babbie, E. (2012). Social research counts. Nelson Education.

Barney, J. B., \& Clark, D. N. (2007). Resource-based theory: Creating and sustaining competitive advantage. Oxford University Press on Demand.

Chijioke, N., Vu, H. M., \& Olatunji, F. (2018). Influence of strategy formulation drivers on strategic performance. Ekonomicko-manazerske spektrum, 12(2), 15-25.

Creswell, J. W. (2010). Mapping the developing landscape of mixed methods research. SAGE handbook of mixed methods in social \& behavioral research, 2, 45-68.

Decramer, A. (2015). Looking for the Value of Strategic drivers in firm performance and competitiveness. Management Decision, 49(3), 468-483.

Dhungana, B. P. (2013). Strengthening the competitiveness of small and medium enterprises in the globalization process: Prospects and challenges. Investment promotion and enterprise development bulletin for Asia and the Pacific, 1, 1-32.

Dunkelberg, W., Moore, C., Scott, J., \& Stull, W. (2013). Do entrepreneurial goals matter? Resource allocation in new owner-managed firms. Journal of Business Venturing, 28(2), 225-240.

Fayol, H., and Storrs C. (2013). General and Industrial Strategic Management. East ford USA: Martino. Fine books.

Fonseka, M. M., Tian, G. L., \& Li, L. C. (2014). Impact of financial capability on firms' competitiveness and sustainability: Evidence from highly regulated Chinese market. Chinese Management Studies.

Foss, N. J., Klein, P. G., Lien, L. B., Zellweger, T., \& Zenger, T. (2020). Ownership competence. Strategic Management Journal.

Gates, L. P., (2010). Strategic Planning with Critical Success factors and Future Scenarios: An Integrated Strategic Planning Framework. Hanscom AFB, MA: Carnegie Mellon University.

Kanyari, J. W., \& Namusonge, P. (2017). Factors that influence the Kenyan youth entrepreneurs towards the youth enterprise development fund: a case study of Gatundu South District, Kenya.

Klingebiel, R., \& Rammer, C. (2014). Resource allocation strategy for innovation portfolio management. Strategic Management Journal, 35(2), 246-268.

Kraaijenbrink, J., Spender, J. C., \& Groen, A. J. (2010). The resource-based view: A review and assessment of its critiques. Journal of management, 36(1), 349-372. 
Journal of Business and Strategic Management

ISSN 2520-0402 (Online)

Vol.6, Issue No. 2, pp 25-41, 2021

$\underline{\text { www.carijournals.org }}$

López Salazar, A., Contreras Soto, R., \& Espinosa Mosqueda, R. (2012). The impact of financial decisions and strategy on small business competitiveness. Global Journal of business research, 6(2), 93-103.

Mapetere, D., Mavhiki, S., Nyamwanza, T., Sikomwe, S., \& Mhonde, C. (2012). Strategic Role of leadership in strategy implementation in Zimbabwe's state owned enterprises. International Journal of Business and Social Science, 3 (16)

Moghli, A. A. A., Abdallah, G. M., \& Muala, A. (2012). Impact of Innovation on Realizing Competitiveness in Banking Sector in Jordan. American Academic \& Scholarly Research Journal, $4(5), 1-9$.

Muia, K. (2011). Determinants of Growth of Firms Through Mergers and Acquisitions in Kenya: A Study of Firms Listed at the Nairobi Stock Exchange. African Journal of Business \& Management. 2(7).

Munguti, J. M., Musa, S., Orina, P. S., Kyule, D. N., Opiyo, M. A., Charo-Karisa, H., \& Ogello, E. O. (2014). An overview of current status of Kenyan fish feed industry and feed management practices, challenges and opportunities.

Mutindi, U. J. M., Namusonge, G. S., \& Obwogi, J. (2013). Effects of strategic management drivers on organizational performance: a survey of the hotel industry in Kenyan coast.

Mutunga, S. L., Minja, D., \& Gachanja, P. (2014). Innovative adaptation and operational efficiency on sustainable competitiveness of food and beverage firms in Kenya. European Journal of Business and Innovation Research, 2(2), 32-50.

Oltra, M.J. and Flor, M.L.(2010), The moderating effect of business strategy on the relationship between operations strategy and firms results, International Journal of operations \& production management, Vol.30 No.6,pp.612-638.

Ortiz, F. C., \& Pacheco, M. O. (2013). Study on the Competitiveness of the Mexican Sugar Industry. Banco de Mexico, Documentos de Investigacion, Working Papers.

Peppard, J., \& Rylander, A. (2001). Using an intellectual capital perspective to design and implement a growth strategy:: the case of APiON. European Management Journal, 19(5), 510525.

Pernierl, P. (2015). Competitiveness and entrepreneurial power: The dark side of entrepreneurship. Journal of Small Business and Enterprise Development, 2(1), 9-23.

Porck, J. P., van Knippenberg, D., Tarakci, M., Ateş, N. Y., Groenen, P. J., \& de Haas, M. (2020). Do group and organizational identification help or hurt intergroup strategic consensus?. Journal of Management, 46(2), 234-260. 
Ribau, C. P., Moreira, A. C., \& Raposo, M. (2018). SME internationalization research: Mapping the state of the art. Canadian Journal of Administrative Sciences/Revue Canadienne des Sciences de l'Administration, 35(2), 280-303.

Tafirei, C.M. (2014). A Comparative Study of Strategic drivers of SMEs and Large-Sized Business Organizations in Emerging Economies: The Case of Sweden. Strategic Change, 24(6), 553-567.

Wernerfelt, B. (1984). A resource-based view of the firm. Strategic management journal, 5(2), 171-180. 